\title{
Ecology of Preimaginal Culicine Mosquitoes in Rock Pools on Inselbergs within
} Kaduna State, Nigeria

Obi O.A. ${ }^{1}$, Nock I.H. ${ }^{2}$, Adebote D.A. ${ }^{2}$

${ }^{1}$ Department of Zoology, Federal University of Agriculture, Makurdi, Benue State, Nigeria

${ }^{2}$ Department of Zoology, Ahmadu Bello University, Zaria, Kaduna State, Nigeria

\Corresponding author email: okeyobi1160@yahoo.com

Journal of Mosquito Research, 2019, Vol.9, No.5 doi: 10.5376/jmr.2019.09.0005

Received: 03 Jan., 2019

Accepted: 10 Apr., 2019

Published: 12 Sep., 2019

Copyright (C) 2019 Obi et al., This is an open access article published under the terms of the Creative Commons Attribution License, which permits unrestricted use, distribution, and reproduction in any medium, provided the original work is properly cited.

Preferred citation for this article:

Obi O.A., Nock I.H., and Adebote D.A., 2019, Ecology of preimaginal culicine mosquitoes in rock pools on inselbergs within Kaduna State, Nigeria, Journal of Mosquito Research, 9(5): 35-48 (doi: $10.5376 / \mathrm{jmr} .2019 .09 .0005)$

\begin{abstract}
Ecological investigations were conducted between June and October 2013 on the species composition of culicine mosquitoes breeding in discrete rock pool habitats and chemistry of their microhabitats on inselbergs within Kaduna State, Nigeria. Standard soup ladle dipper $(0.105 \mathrm{~L}$ capacity) was used to obtain representative samples of preimaginal stages of mosquito into plastic bowls. HANNA HI98129 pH/EC/TDS/TEMP meter was used to determine habitats' physicochemical parameters in situ. Habitats' turbidity, alkalinity, total suspended solids, total hardness, Chemical oxygen demand, phosphate and nitrate levels were determined following standard laboratory protocols. Fully developed (4th instar) larvae were preserved with 70\% ethanol in labelled specimen bottles while larvae in their lower instars were nurtured on baker's yeast diet in the laboratory, prior to preservation. Mosquitoes were identified microscopically to species by means of pictorial morphological keys. Data were analysed by ANOVA, Pearson correlation and principal component analyses. A total of 269(69.69\%) of the 386 rock pools examined were positive with culicine mosquitoes, yielding 31691 larvae belonging to seven species. These included 30366(95.97\%) Aedes vittatus, 266(0.84\%) Culex albiventris, 105(0.33\%) Culex horridus, 241(0.76\%) Culex macfiei, 139(0.44\%) Culex pipiens pipiens, 523(1.65\%) Culex perfidiosus, 1(0.003\%) Culex simpsoni and $1(0.003 \%)$ Culex tigripes. The mosquitoes bred as sole, double, triple and quadruple conspecific, heterospecific, congeneric and heterogeneric combinations. Specific ranges of breeding habitats' parameters were depths $(0.4 \sim 65 \mathrm{~cm})$, surface areas $\left(1.5 \sim 1970 \mathrm{~m}^{2}\right)$, temperatures $\left(22.8^{\circ} \mathrm{C} \sim 36.5^{\circ} \mathrm{C}\right), \mathrm{pH}(7.05 \sim 12.69)$, TDS $(0 \sim 276 \mathrm{ppm}), \mathrm{EC}(0 \sim 572 \mu \mathrm{s} / \mathrm{cm}), \mathrm{TSS}(10 \sim 150 \mathrm{mg} / \mathrm{L})$, turbidity (1.97 178NTU), hardness $(30.3 \sim 545.4 \mathrm{mg} / \mathrm{L}), \quad \mathrm{COD}(80 \sim 480 \mathrm{mg} / \mathrm{L}), \quad \mathrm{PO}_{4}{ }^{3-}(\mathrm{mg} / \mathrm{L}), \quad \mathrm{NO}_{3}{ }^{-}(8.5 \sim 109.4 \mathrm{mg} / \mathrm{L})$ and alkalinity $(2 \sim 111 \mathrm{mg} / \mathrm{L})$. Water temperature and hardness were determinants of spatial distribution of mosquitoes in the rock pools. TDS, EC and akalinity significantly correlate with mosquito larval abundance in rock pools $(p<0.001)$. The study observed widespread breeding of noxious mosquito vectors of diseases in rock pools throughout the State and recommends their targeted control in situ.

Key words: Preimaginal culicines; Rock pools; Inselbergs; Physicochemical parameters
\end{abstract}

\section{Background}

Mosquitoes are unambiguously the most important vectors of infectious disease-causing agents that tremendously affect global health, with over half of the global human population at risk of exposure to mosquito-transmitted infections and more than 1 billion cases of such infections reported each year (Famakinde, 2018). Mosquito-transmitted diseases are the major causes of morbidity and mortality in sub-Saharan Africa where yellow fever epidemics and other arboviral diseases have had debilitating effects on human populations (Olayemi et al., 2010). In Nigeria, these diseases constitute the number one public health challenge, imparting negatively on the country's economic development, to the tune of more than 1\% growth penalty per year (Olayemi et al., 2010). These vectors of human and animal diseases have diverse habits that allow them to colonize different kinds of environments (Rueda, 2008). The immature stages of mosquito are thus found in a variety of aquatic habitats including ponds, streams, ditches, swamps, marshes, temporary and permanent pools, rock holes, tree holes, crab holes, lake margins, plant containers (leaves, fruits, husks, tree holes, bamboo internodes), artificial containers (tyres, tin cans, flower vases, bird feeders), and other habitats (Day, 2016). Mosquito species exhibit a remarkable diversity of oviposition behaviours that ensure eggs are deposited into microenvironments conducive for successful larval development and the emergence of the next mosquito generation (Day, 2016). This oviposition preference of adult female mosquitoes and the ability of immature stages of mosquitoes to adapt to both biotic and 
abiotic environmental conditions of a given aquatic habitat determine the abundance and distribution of immature mosquitoes (Dejenie et al., 2002; Day, 2016). Part of the problems militating against effective and sustained control of mosquitoes and the diseases transmitted by them is the overt advantages available to mosquitoes to breed in diverse aquatic media that are naturally occurring and or the creation of human activities. Rocky outcrops have a profound influence on the distribution and abundance of biodiversity worldwide (Lindenmayer et al., 2008). Such environments are well documented as biological hotspots which often support unique biotic communities and high levels of endemism while the composition of mosquito fauna of a pool is influenced by its temporary or permanent nature (Lindenmayer et al., 2008).

These small bodies of water undergo recurrent, variable wet-dry phases, making them temporary intermittent pools (Levas, 2006). The relatively small nature of rock pools and the few macroscopic biota constituents make it easier to determine their community structure. Pool structure is determined by a complex set of biological and physical factors that interact to develop a patchy habitat (Wallenstein et al., 2010). Interactions between climate and geology (e.g. limestone, sandstone, granite) generally determine the morphology and hydrology of rock pool habitats, with hydro periods ranging from several days up to the whole year. Pool volume is usually small, resulting in strongly fluctuating environmental conditions, low conductivity and wide variations in $\mathrm{pH}$ (from 4.0 to 11.0) and temperature (from freezing point to $40^{\circ} \mathrm{C}$ ) often with well marked diel cycles (Wallenstein et al., 2010). Rock pools in general are oligotrophic systems open to nutrient inputs and outputs (Jocque et al., 2010) and even a brief rain shower may, depending on the topography, fill a rock pool to overflowing.

Few attempts have been made to describe the distribution patterns of rock pool biotas in relation to any suspected influence of physicochemical conditions to which the pools are subject and how these in turn affect species composition and relative abundance of preimaginal mosquitoes (Obi et al., 2017). Typically in areas where mosquito breed in rock pools, not every pool is often colonized by juvenile stages to the extent that several apposed pools could be devoid of mosquito while few other neighbouring pools have high density of larvae. Such disjointed larval colonization has not been fully investigated to unravel its ecologic undertone and potential applicability in control. This study therefore was designed to unravel key ecological factors that modulate the breeding of mosquito vectors of human and animal diseases in rock pool habitats in Kaduna State, Northern Nigeria, where such habitats are known to be abundant but relatively inaccessible to routine control operations. The knowledge of inherent pool characteristics that make rock pools to be desirable or otherwise for mosquito breeding will enhance knowledge of the biology of the insects and the ability to control them.

\section{Materials and Methods}

\subsection{Study area and sites}

This study was carried out on the rocky outcrop of Kaduna State located between (Lat $8^{\circ} 30^{\prime} 0^{\prime \prime} \mathrm{N}$ and $11^{\circ} 30^{\prime} 0^{\prime} \mathrm{N}$ ) and (Long $6^{\circ} 0^{\prime} 0^{\prime} \mathrm{E}$ and $8^{\circ} 30^{\prime} 0^{\prime \prime} \mathrm{E}$ ), Northern Nigeria (Figure 1). Vegetation type comprises tropical grassland in the southern Guinea savannah to Sudan savannah (NACD, 2013). Rainfall is heavy in the southern part and around Zaria in the northern part; with average rainfall of about $1016 \mathrm{~mm}$ (NACD, 2013). The wet season is usually from April through October with great variations as one move northwards. The two climatic conditions (wet and dry) in the state greatly influence activities of the people, who are predominantly engaged in agriculture. Available rock pools sampled for mosquito breeding were spatially distributed in twenty one (21) settlements endowed with inselbergs. Sampling locations consisted of nine local government areas out of the 23 local government areas of the state. The southern Guinea savanna parts of the state that were sampled included the following local government areas: Jaba, Jema'a, Kagarko, Kajuru, Kaduna-North, Igabi, and Giwa (partly Guinea and partly Sudan savanna) in the following settlements: Kwoi, Nok, Samban-Gida, Kagoma, Chori, Kagarko, Jere, Tudun-Mare, Kufana, Kajuru, Kujama, Baban-Sora, Malali, Kangimi, and Kufena. In Sudan savanna, Sabon-Gari local government area was sampled only in Hanwa settlement. Danmagaji, Wusasa, Dutsen-Abba, Dumbi, and Zango-Aya settlements were sampled in Zaria local government area. 
Journal of Mosquito Research 2019, Vol.9, No.5, 35-48

$\mathrm{http} / / /$ emtoscipublisher.com/index.php/jmr

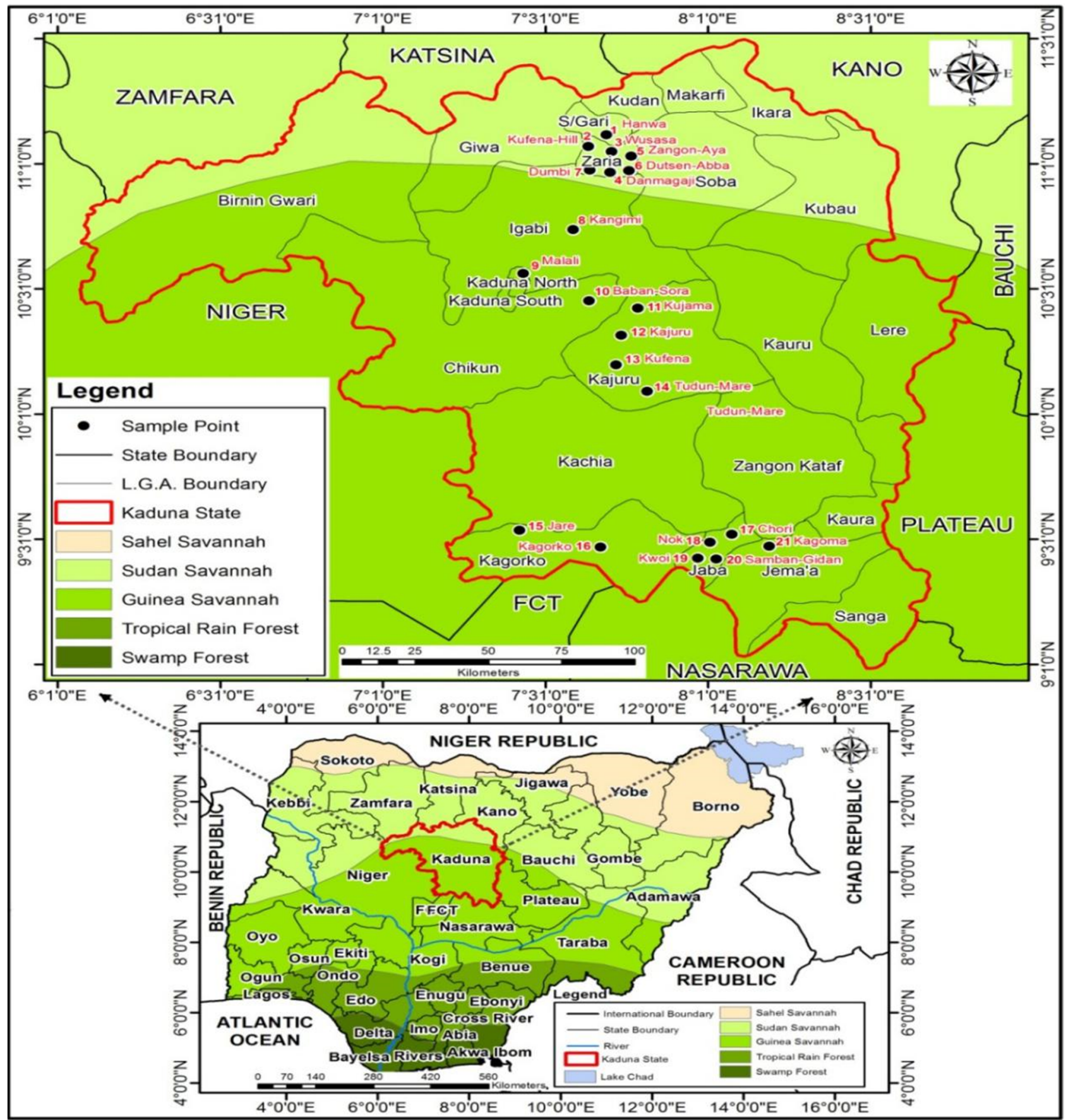

Figure 1 Kaduna State showing sampling sites

The undulating plateaux possess several depressions in which rainwater collects to form discrete pools during the rainy season. These collections of water serve as effective breeding habitats for mosquitoes. The State occupies part of the central position of the northern part of Nigeria (with Kaduna as its capital) and shares common borders with Zamfara, Katsina, Niger, Kano, Bauchi and Plateau states. To the South-West, the state shares a border with the Federal Capital Territory, Abuja. Kaduna State is the fourth most populous State in the federation and represents a major focus and centre of political and economic activities in the nation. The State occupies an area of approximately $48,473.2$ square kilometers and has a population of $6,113,503$ and a population density of 130 people per square kilometre. It accounts for $4.3 \%$ of Nigeria's total population (NPC, 2006). 


\subsection{Study duration and determination of geographic attributes}

The study was conducted for five (5) months between June and October, 2013. Available true rock pools (as opposed to edged rock pools) were searched fortnightly on the inselbergs as much as access permitted, assisted by indigenous volunteers from the respective sampled locations. A GARMIN e Trex Venture HC hand held global positioning system (GPS) was used to determine the geographic coordinates, altitude above sea level and altitude above the surroundings of the rock pools in the settlements across the State.

\subsection{Determination of physicochemical parameters of rock pools}

Mean depth of water in each rock pool was determined by dipping a metal rod to touch the bottom of the pool at three locations and the wet region of the rod measured against a transparent ruler. The mean of the three measurements were taken to determine the mean depth of each rock pool. The surface areas of rock pools were determined with a metre rule to measure the length and width of each pool after making the necessary adjustment for irregular surfaces (Adebote et al., 2008). The area of each pool was then calculated. The $\mathrm{pH}$, electrical conductivity, total dissolved solids and temperature of water in each rock pool were determined by means of a HANNA HI 98129 pH/ EC/TDS/Temp metre. Other parameters, which included turbidity, total alkalinity, total suspended solids, total hardness, dissolved oxygen, biological oxygen demand, chemical oxygen demand, phosphate and nitrate, were determined according to standard protocols described by APHA (1998).

\subsection{Sampling and specimen preservation techniques}

Samplings were carried out forthnightly within the study locations that transverse across the vegetational zones of the State for a period of five (5) months. Ten dips of water in every other rock pool were obtained with a plastic soup ladle dipper (0.105 L capacity) (Service, 1976). Water from each pool was collected in a white plastic bowl and carefully observed for the presence of preimaginal mosquitoes. Culicine larvae, in their fourth instar, were concentrated in a sieve and carefully picked with dropping pipette into labeled specimen bottles and preserved in $70 \%$ ethanol. Culicine larvae in their lower instars were nurtured to the fourth instar in labeled plastic bowls on a diet of baker's yeast and subsequently preserved in 70\% ethanol in appropriately labeled specimen bottles.

\subsection{Mosquito species identification}

All the mosquitoes collected were morphologically identified to the species taxon and counted under the x50 magnification of a stereo-microscope. Culicine mosquitoes were identified based on the pictorial keys of Hopkins (1952).

\subsection{Data analysis}

Pearson's correlation analysis was used to establish relationships between the physicochemical parameters of water and abundance of species of mosquito breeding therein. Principal component analysis (PCA) was used to examine the relationships (interaction effects) amongst physicochemical parameters of water and to select water parameters that were most useful in distinguishing mosquito species habitats in rock pools. One-way analysis of variance (ANOVA) was employed to test for significant differences of physicochemical factors in relation to mosquito abundance, using least significant difference to separate means that differed significantly. All levels of statistical significance were determined at $p<0.05$.

\section{Results}

The relative abundance of mosquito species in the study area was expressed as the corresponding percentage of the total number of preimaginal culicines collected (Table 1). A total of 386 rock pools distributed in twenty one settlements on inselbergs were observed for microhabitats supportive of preimaginal culicine mosquitoes. The actual height of the inselbergs was determined as the resultant of the height above sea level and above the surroundings. A total of 31642 mosquito larvae were collected from 269 (69.7\%) rock pools on inselbergs with height ranging from $597 \mathrm{~m}$ to $811 \mathrm{~m}$ above sea level. Rock pools on Kufana inselberg recorded zero abundance of preimaginal culicine mosquitoes. Malali inselberg had the highest $(100 \%)$ percentage larval positivity while Zango-Aya inselberg was observed with higher number of pools. The least larval positivity $(31.8 \%)$ was observed on Dutsen-Abba inselbergs. The highest number of larvae was collected from Hanwa inselberg while the least was 
collected from Nok inselberg. The relative abundance of larvae was highest on Wusasa inselberg which also had the highest larval density per pool while the least larval abundance was observed on Tudun-Mare inselberg which also had the least larval density. Kujama inselberg was the tallest inselberg at a height of $76 \mathrm{~m}$ while Kangimi inselberg was the least in terms of height (4 m) amongst the inselbergs.

Table 1 Cont'd Occurrence and abundance of mosquito larvae in rock pools on inselbergs in Kaduna State, Nigeria

\begin{tabular}{|c|c|c|c|c|c|c|c|}
\hline $\begin{array}{l}\text { Inselbergs } \\
\text { (Coordinates) }\end{array}$ & $\begin{array}{l}\text { Altitude above } \\
\text { sea level (m) }\end{array}$ & $\begin{array}{l}\text { Height above } \\
\text { surrounding area } \\
(\mathrm{m})\end{array}$ & $\begin{array}{l}\text { No. of } \\
\text { pools } \\
\text { examined }\end{array}$ & $\begin{array}{l}\text { No. of pools } \\
\text { positive }(\%)\end{array}$ & $\begin{array}{l}\text { No. of larvae } \\
\text { collected (\%) }\end{array}$ & $\begin{array}{l}\text { Relative } \\
\text { abundance of } \\
\text { larvae }\end{array}$ & $\begin{array}{l}\text { Larval No. } \\
\text { per pool } \\
\text { (density) } \\
\end{array}$ \\
\hline $\begin{array}{l}\text { Kujama } \\
\left(10^{\circ} 28^{\prime} 23.7^{\prime \prime N}\right) \\
\left(07^{\circ} 37^{\prime} 29.3^{\prime \prime E}\right)\end{array}$ & 736 & 76 & 16 & $11(68.8)$ & $1425(4.5)$ & 129.5 & 89.1 \\
\hline $\begin{array}{l}\text { Kwoi } \\
\left(09^{\circ} 27^{\prime} 12.9^{\prime \prime N}\right) \\
\left(08^{\circ} 00^{\prime} 53.4^{\prime \prime} \mathrm{E}\right)\end{array}$ & 794 & 14 & 16 & $11(68.8)$ & $911(2.9)$ & 82.8 & 56.9 \\
\hline $\begin{array}{l}\text { Malali } \\
\left(10^{\circ} 32^{\prime} 41.8^{\prime \prime N}\right) \\
\left(07^{\circ} 28^{\prime} 15.9^{\prime \prime} \mathrm{E}\right)\end{array}$ & 616 & 18 & 10 & $10(100.0)$ & $3476(11.0)$ & 347.6 & 347.6 \\
\hline $\begin{array}{l}\text { Nok } \\
\left(09^{\circ} 28^{\prime} 46.3^{\prime \prime N}\right) \\
\left(08^{\circ} 01^{\prime} 19.3^{\prime \prime} \mathrm{E}\right)\end{array}$ & 811 & 67 & 14 & $8(57.1)$ & $242(0.8)$ & 30.3 & 17.3 \\
\hline $\begin{array}{l}\text { Samban-Gida } \\
\left(09^{\circ} 27^{\prime} 06.4^{\prime \prime N}\right) \\
\left(08^{\circ} 03^{\prime} 10.7^{\prime \prime} \mathrm{E}\right)\end{array}$ & 798 & 24 & 20 & $13(65.0)$ & $705(2.2)$ & 54.2 & 35.3 \\
\hline $\begin{array}{l}\text { Tudun-Mare } \\
\left(10^{\circ} 19^{\prime} 15.0^{\prime \prime N}\right) \\
\left(07^{\circ} 42^{\prime} 57.4^{\prime \prime} \mathrm{E}\right)\end{array}$ & 722 & 22 & 23 & $11(47.8)$ & $322(1.0)$ & 29.3 & 14.0 \\
\hline Total & & & 386 & $269(69.7)$ & 31642 & 117.6 & 81.9 \\
\hline
\end{tabular}

Four species of preimaginal culicine mosquitoes which included Ae. vittatus, Culex perfidiosus, Cx. pipiens pipiens and Cx. simpsoni bred in rock pools in Sudan savanna of Kaduna State (Table 2). Aedes vittatus 14937 (98.2\%) preponderates at high proportion (above 80\%) amongst the four species of mosquito larvae that bred in rock pools within Sudan Savanna. However, Hanwa inselberg had the highest larval abundance of Ae. vittatus followed by Danmagaji and Wusasa inselbergs where Ae. vittatus bred prolifically as single species. Danmagaji, Hanwa and Wusasa inselbergs supported the breeding of only Ae. vittatus while Dumbi inselberg supported the breeding of three species of Culex mosquitoes. Seven species of mosquito larvae bred in rock pools on fourteen inselbergs in the Guinea savanna of the State (Table 3). These included one species of Aedes and six species of Culex mosquitoes. By far, Ae. vittatus (92.2\%) was the most abundant species which ranged from (77.8\% 100.0\%) in six of the seven inselbergs, with the exception of Kufana inselberg. This part of the State had the highest species diversity of Culex mosquitoes, dominated by $C x$. albiventris with $C x$. macfiei being the most widespread in terms of inselberg colonisation. The highest larval abundance of Ae. vittatus was observed on the Jere inselberg. Culex tigripes recorded the least larval abundance which was observed only on the Nok inselberg. Kajuru, Kwoi and Nok inselbergs supported the breeding of four different species of preimaginal culicines. Chori inselberg had the least diversity of only one mosquito species breeding in its rock pools. Breeding patterns of mosquitoes in rock poolranged from one to four congeneric and heterogeneric species (Table 4). 
Journal of Mosquito Research 2019, Vol.9, No.5, 35-48

$\mathrm{http} / / /$ emtoscipublisher.com/index.php/jmr

Table 2 Species composition and abundance of mosquito larvae in Sudan savanna of Kaduna State, Nigeria

\begin{tabular}{lccccc}
\hline Inselbergs & \multicolumn{3}{c}{ Mosquito species and abundance } & Total \\
\cline { 2 - 5 } & Ae. vittatus & Cx. perfidiosus & Cx. p. pipens & Cx. simpsoni \\
\hline Danmagaji & $2196(100)$ & $0(0.0)$ & $0(0.0)$ & $0(0.0)$ & 2196 \\
Dumbi & $1002(85.6)$ & $146(12.5)$ & $21(1.8)$ & $1(0.1)$ & 1170 \\
Dutsen-Abba & $306(97.5)$ & $8(2.5)$ & $0(0.0)$ & $0(0.0)$ & 314 \\
Hanwa & $5042(100)$ & $0(0.0)$ & $0(0.0)$ & $0(0.0)$ & 5042 \\
Kufena & $1085(100)$ & $0(0.0)$ & $0(0.0)$ & $0(0.0)$ & 1085 \\
Wusasa & $4210(100)$ & $0(0.0)$ & $0(0.0)$ & $0(0.0)$ & 4210 \\
Zango-Aya & $1096(91.9)$ & $6(0.5)$ & $91(7.6)$ & $0(0.0)$ & 1193 \\
Total & $14937(98.2)$ & $160(1.05)$ & $112(0.74)$ & $1(0.01)$ & 15210 \\
\hline
\end{tabular}

Table 3 Species composition and abundance of mosquito larvae in Guinea savanna of Kaduna State, Nigeria

\begin{tabular}{|c|c|c|c|c|c|c|c|c|}
\hline \multirow[t]{2}{*}{ Inselbergs } & \multicolumn{7}{|c|}{ Mosquito species and abundance } & \multirow[t]{2}{*}{ Total } \\
\hline & Ae. vittatus & $\begin{array}{l}C x . \\
\text { albiventris }\end{array}$ & Cx. horridus & Cx. macfiei & $\begin{array}{l}\text { Cx. } \\
\text { perfidiosus }\end{array}$ & $\begin{array}{l}\text { Cx.p. } \\
\text { pipiens }\end{array}$ & $\begin{array}{l}C x . \\
\text { tigripes }\end{array}$ & \\
\hline Baban-Sora & 1623(99.3) & $0(0.0)$ & $0(0.0)$ & $6(0.4)$ & $0(0.0)$ & $2(0.1)$ & $0(0.0)$ & 1631 \\
\hline Kajuru & $1019(77.8)$ & $0(0.0)$ & $0(0.0)$ & $30(2.3)$ & $245(18.7)$ & $14(1.1)$ & $0(0.0)$ & 1308 \\
\hline Kangimi & $1427(99.0)$ & $0(0.0)$ & $0(0.0)$ & $0(0.0)$ & $0(0.0)$ & $0(0.0)$ & $0(0.0)$ & 1427 \\
\hline Kufana & $0(0.0)$ & $0(0.0)$ & $0(0.0)$ & $0(0.0)$ & $0(0.0)$ & $0(0.0)$ & $0(0.0)$ & 0 \\
\hline Kujama & $1389(97.2)$ & $1(0.0)$ & $0(0.0)$ & $35(2.4)$ & $0(0.0)$ & $0(0.0)$ & $0(0.0)$ & 1425 \\
\hline Malali & $3476(100.0)$ & $0(0.0)$ & $0(0.0)$ & $0(0.0)$ & $0(0.0)$ & $0(0.0)$ & $0(0.0)$ & 3476 \\
\hline Tudun-Mare & $320(98.8)$ & $0(0.0)$ & $0(0.0)$ & $0(0.0)$ & $0(0.0)$ & $2(0.6)$ & $0(0.0)$ & 322 \\
\hline Chori & $656(100.0)$ & $0(0.0)$ & $0(0.0)$ & $0(0.0)$ & $0(0.0)$ & $0(0.0)$ & $0(0.0)$ & 656 \\
\hline Jere & 2657(99.8) & $0(0.0)$ & $0(0.0)$ & $0(0.0)$ & $0(0.0)$ & $0(0.0)$ & $0(0.0)$ & 2657 \\
\hline Kagarko & $494(56.8)$ & $264(30.4)$ & $105(12.1)$ & $0(0.0)$ & $0(0.0)$ & $0(0.0)$ & $0(0.0)$ & 863 \\
\hline Kagoma & $785(96.7)$ & $0(0.0)$ & $0(0.0)$ & $24(3.0)$ & $0(0.0)$ & $0(0.0)$ & $0(0.0)$ & 809 \\
\hline Kwoi & $764(83.9)$ & $0(0.0)$ & $0(0.0)$ & $22(2.4)$ & $118(13.0)$ & $7(0.8)$ & $0(0.0)$ & 911 \\
\hline Nok & $236(97.5)$ & $1(0.1)$ & $0(0.0)$ & $4(1.7)$ & $0(0.0)$ & $0(0.0)$ & $1(0.4)$ & 242 \\
\hline Samban-Gida & $583(82.6)$ & $0(0.0)$ & $0(0.0)$ & $120(17.0)$ & $0(0.0)$ & $2(0.3)$ & $0(0.0)$ & 705 \\
\hline Total & $15429(93.09)$ & $266(1.61)$ & $105(0.64)$ & $241(1.46)$ & $363(2.20)$ & $27(0.16)$ & $1(0.01)$ & 16432 \\
\hline
\end{tabular}

Note: Figure in brackets represents abundance percentage (\%)

Aedes vittatus predominated as sole species in 213(79.2\%) rock pool on nineteen inselbergs. The heterogeneric pairs of Ae. vittatus and Cx. pipiens pipiens predominated as double species per pool in $8(3.0 \%)$ rock pools on five inselbergs. Congeneric pair of $C x$. albiventris and $C x$. horridus was encountered breeding per pool on Kagarko inselberg. Single combination of triple and quadruple species of mosquitoes breeding per pool was observed with the trio of Ae. vittatus, Cx. macfiei and Cx. albiventris on one inselberg. The physicochemical parameters of the rock pools utilized for breeding by eight species of culicine mosquito larvae are shown in Table 5. Aedes vittatus bred in rock pools with the shallowest depth while Cx. perfidiosus bred in the deepest pools. Ae. vittatus and $C x$. macfiei bred in rock pools with the largest surface areas. Culex macfiei bred in rock pools with the largest mean surface area while $C x$. tigripes bred in pools with the least surface area. Water temperature in the rock pools ranged from $22.8^{\circ} \mathrm{C}$ to $36.5^{\circ} \mathrm{C}$; the high temperature extremes were associated with Ae. vittatus. pH of the rock pools varied from neutral $(\mathrm{pH}$ 7.05) to strong alkalinity ( $\mathrm{pH}$ 12.69). The culicines occurred partly in neutral pools ( $\mathrm{pH} 7.05 \sim 7.54)$ and partly in strong alkaline pools (pH 8.89 12.69). Culex macfiei amongst other culicines bred in pools with strongest range of alkalinity (pH 10.32 12.19). Aedes vittatus, Cx. perfidiosus and $C x$. pipiens pipiens was associated consistently with the total dissolved solid and electrical conductivity in the rock pools. Culex albiventris, Cx. horridus and Cx. simpsoni occurred once in pools with total dissolved solid (122, 122 and 99 ppm respectively) and electrical conductivity (210, 210 and $198 \mu \mathrm{s} / \mathrm{cm}$ respectively). 
Table 4 Breeding patterns of mosquito species in rock pools on inselbergs in Kaduna State, Nigeria

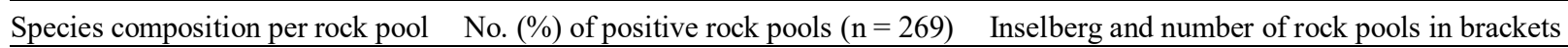

(a) Single species

Aedes vittatus

213(79.2)

Culex macfiei
Culex pipiens pipiens
Culex tigripes
Total

$1(0.4)$

$1(0.4)$

$1(0.4)$

Tota

$216(80.3)$

(b) Double species

Aedes vittatus + Culex albiventris

2(0.7)

Aedes vittatus + Culex macfiei

Aedes vittatus + Culex perfidiosus

Aedes vittatus + Culex pipiens

8(3.0)

pipiens

Culex albiventris + Culex horridus

Total

$1(0.4)$

(c) Triple species

Aedes vittatus + Culex macfiei +

Culex perfidiosus

Total

(d) Quadruple species

Aedes vittatus + Culex macfiei+

Culex perfidiosus + Culex pipiens pipiens

Total
Baban-Sora (7), Chori (13), Danmagaji (8), Dutsen-Abba (5), Hanwa (25), Jere (19), Kagarko (6), Kagoma (16), Kajuru (9), Kangimi (16), Kufena(17), Kujama (8), Kwoi (10), Malali (10), Nok (5), Tudun- Mare (8), Samban-Gida (10), Wusasa (6), Zango-Aya (15)

Nok (1)

Zango-Aya (1)

Nok (1)

Kujama (1), Nok (1)

Kujama (1)

Dumbi (1), Dutsen-Abba (2), Kajuru (1),

Zango-Aya (1)

Dumbi (1), Kajuru (2), Samban-Gida (2),

Tudun-Mare (2), Zango-Aya (1)

Kagarko (1)

Kajuru (1)

Kwoi (1)

Analysis of Variance (ANOVA) showed that the abundance of mosquito larvae significantly differed with $\mathrm{pH}$ of the rock pools $(p<0.05)$. Highly significant different existed with the abundance of mosquito larvae to total dissolved solid, electrical conductivity and alkalinity of the rock pools $(p<0.001)$. The abundance of mosquito larvae did not differ significantly with depth, surface area, hardness and turbidity of the rock pools $(p>0.05)$. Principal component analysis (PCA) indicated that interaction effects of physicochemical parameters of breeding microhabitats are largely similar and negatively correlated with the study locations (Figure 2). Temperature, electrical conductivity and total dissolved solid strongly correlated $(p<0.05)$ with the abundance of mosquito larvae in rock pools on Dumbi inselberg while nitrate and turbidity were vital in influencing mosquito breeding on Hanwa inselberg. Water hardness also correlated strongly $(p<0.05)$ with the abundance of mosquito larvae on Kufena inselberg. The colonization of mosquitoes in rock pools on inselbergs did not significantly correlate with chemical oxygen demand and $\mathrm{pH}(p>0.05)$. 


\section{Journal of Mosquito Research 2019, Vol.9, No.5, 35-48}

http://emtoscipublisher.com/index.php/jmr

Table 5 Range of physicochemical parameters supportive of culicine mosquito larvae breeding in rock pools on inselbergs in Kaduna State, Nigeria

\begin{tabular}{|c|c|c|c|c|c|c|c|c|c|c|c|c|c|}
\hline \multirow[t]{2}{*}{ Species } & \multirow[b]{2}{*}{ Depth $(\mathrm{cm})$} & \multirow[b]{2}{*}{$\begin{array}{l}\text { Surface } \\
\text { area }\left(\mathrm{m}^{2}\right)\end{array}$} & \multirow[b]{2}{*}{$\begin{array}{l}\text { Temp } \\
\left({ }^{\circ} \mathrm{C}\right)\end{array}$} & \multirow[b]{2}{*}{$\mathrm{pH}$} & \multicolumn{4}{|c|}{ Physicochemical parameters } & \multirow[b]{2}{*}{ COD (mg/l) } & \multirow[b]{2}{*}{$\mathrm{PO}_{4}^{-3}(\mathrm{mg} / \mathrm{l})$} & \multirow[b]{2}{*}{$\mathrm{NO}^{-3}(\mathrm{mg} / \mathrm{l})$} & \multirow[b]{2}{*}{$\begin{array}{l}\text { ALKA } \\
(\mathrm{mg} / \mathrm{l})\end{array}$} & \multirow[b]{2}{*}{ TURB (mg/l) } \\
\hline & & & & & TDS (ppm) & $\mathrm{EC}(\mu \mathrm{s} / \mathrm{cm})$ & $\mathrm{TSS}(\mathrm{mg} / \mathrm{l})$ & $\begin{array}{l}\text { HARD } \\
(\mathrm{mg} / \mathrm{l})\end{array}$ & & & & & \\
\hline Ae. vittatus & $\begin{array}{l}0.4-41 \\
(5.9 \pm 0.35)^{\mathrm{a}}\end{array}$ & $\begin{array}{l}1.5-1970 \\
(60.7 \pm 8.6)^{\mathrm{a}}\end{array}$ & $23.3-36.5$ & $\begin{array}{l}7.05-12.69 \\
(10.9 \pm 0.1)^{\mathrm{ab}}\end{array}$ & $\begin{array}{l}0.0-276 \\
(57.6 \pm 10.9)^{\mathrm{ab}}\end{array}$ & $\begin{array}{l}0.0-572 \\
(117.7 \pm 21.5)^{\mathrm{ab}}\end{array}$ & $\begin{array}{l}10-130 \\
(51.9 \pm 9.2)^{\mathrm{a}}\end{array}$ & $\begin{array}{l}30.3-545.4 \\
(176.5 \pm 26.9)^{\mathrm{a}}\end{array}$ & $\begin{array}{l}80-480 \\
(257.6 \pm 23.2)^{\mathrm{a}}\end{array}$ & $\begin{array}{l}0.16-12.50 \\
(2.63 \pm 0.79)^{\mathrm{a}}\end{array}$ & $\begin{array}{r}8.5-74.70 \\
(23.79 \pm 3.88)^{\mathrm{a}}\end{array}$ & $\begin{array}{l}2.0-111.0 \\
(27.43 \pm 5.57)^{\mathrm{ab}}\end{array}$ & $\begin{array}{l}2.3-92.4 \\
(24.9 \pm 5.4)^{\mathrm{a}}\end{array}$ \\
\hline $\begin{array}{l}C x . \\
\text { albiventris }\end{array}$ & $\begin{array}{l}1.1-41 \\
(15.8 \pm 12.7)^{\mathrm{a}}\end{array}$ & $\begin{array}{l}45-88 \\
(67 \pm 12.4)^{\mathrm{a}}\end{array}$ & $26.6-32$ & $\begin{array}{l}9.87-11.42 \\
(10.7 \pm 0.5)^{\mathrm{abc}}\end{array}$ & $122^{\mathrm{ab}}$ & $210^{\mathrm{ab}}$ & ND & ND & ND & ND & ND & ND & ND \\
\hline Cx. horridus & $5.2^{\mathrm{a}}$ & $88^{\mathrm{a}}$ & 26.8 & $9.87^{\mathrm{c}}$ & $122^{\mathrm{a}}$ & $210^{\mathrm{a}}$ & ND & ND & ND & ND & ND & ND & ND \\
\hline Cx. macfiei & $\begin{array}{l}3.2-14 \\
(7.14 \pm 1.61)^{\mathrm{a}}\end{array}$ & $\begin{array}{l}10.6-1970 \\
(340.1 \pm 272.7)^{\mathrm{a}}\end{array}$ & $22.8-33.4$ & $\begin{array}{l}10.32-12.19 \\
(11.2 \pm 0.3)^{\mathrm{ab}}\end{array}$ & $0^{\mathrm{b}}$ & $0^{\mathrm{b}}$ & $20^{\mathrm{a}}$ & $70.7^{\mathrm{a}}$ & $300^{\mathrm{a}}$ & $0.39^{\mathrm{a}}$ & $9.5^{\mathrm{a}}$ & $12^{\mathrm{b}}$ & $1.97^{\mathrm{a}}$ \\
\hline $\begin{array}{l}\text { Cx. } \\
\text { perfidiosus }\end{array}$ & $\begin{array}{l}2-65 \\
(17 \pm 6.1)^{\mathrm{a}}\end{array}$ & $\begin{array}{l}10.9-120 \\
(57.5 \pm 12.7)^{\mathrm{a}}\end{array}$ & $24.7-35$ & $\begin{array}{l}7.54-11.88 \\
(10.3 \pm 0.4)^{\mathrm{bc}}\end{array}$ & $\begin{array}{l}41-99 \\
(68.7 \pm 16.8)^{\mathrm{ab}}\end{array}$ & $\begin{array}{l}84-198 \\
(136.3 \pm 33.2)^{\mathrm{a}}\end{array}$ & $\begin{array}{l}60-150 \\
(105 \pm 45)^{\mathrm{a}}\end{array}$ & $\begin{array}{l}70-404 \\
(237 \pm 167)^{\mathrm{a}}\end{array}$ & $\begin{array}{l}0-420 \\
(375 \pm 45)^{\mathrm{a}}\end{array}$ & $\begin{array}{l}6.2-11.1 \\
(8.7 \pm 2.5)^{\mathrm{a}}\end{array}$ & $\begin{array}{l}52.70-109.4 \\
(81.1 \pm 28.4)^{\mathrm{a}}\end{array}$ & $\begin{array}{l}33.3-50 \\
(41.5 \pm 8.5)^{\mathrm{a}}\end{array}$ & $\begin{array}{l}17-178 \\
(97.5 \pm 80.5)^{\mathrm{a}}\end{array}$ \\
\hline $\begin{array}{l}\text { Cx.p. } \\
\text { pipiens }\end{array}$ & $\begin{array}{l}1-28 \\
(7.7 \pm 2.4)^{\mathrm{a}}\end{array}$ & $\begin{array}{l}6-345 \\
(70 \pm 28.1)^{\mathrm{a}}\end{array}$ & $26.6-36.1$ & $\begin{array}{l}7.05-12.01 \\
(10.4 \pm 0.4)^{\mathrm{bc}}\end{array}$ & $\begin{array}{r}23-113 \\
(78.3 \pm 30)^{\mathrm{a}}\end{array}$ & $\begin{array}{l}51-198 \\
(121.7 \pm 42.5)^{\mathrm{ab}}\end{array}$ & $\begin{array}{l}10-150 \\
(80 \pm 70)^{\mathrm{a}}\end{array}$ & $\begin{array}{l}373.7-404 \\
(388.9 \pm 15.2)^{\mathrm{a}}\end{array}$ & $\begin{array}{l}100-420 \\
(260 \pm 160)^{\mathrm{a}}\end{array}$ & $\begin{array}{l}0.66-11.10 \\
(5.88 \pm 5.2)^{\mathrm{a}}\end{array}$ & $\begin{array}{l}16.90-109.4 \\
(63.2 \pm 46.3)^{\mathrm{a}}\end{array}$ & $\begin{array}{l}15-50 \\
(32.5 \pm 17.5)^{\mathrm{a}}\end{array}$ & $\begin{array}{l}22.5-178 \\
(100.3 \pm 77.8)^{\mathrm{a}}\end{array}$ \\
\hline $\begin{array}{l}\text { Cx. } \\
\text { simpsoni }\end{array}$ & $20.5^{\mathrm{a}}$ & $23.5^{\mathrm{a}}$ & 31.8 & $10.07^{\mathrm{c}}$ & $99^{\mathrm{a}}$ & $198^{\mathrm{a}}$ & $150^{\mathrm{a}}$ & $404^{\mathrm{a}}$ & $420^{\mathrm{a}}$ & $11.1^{\mathrm{a}}$ & $109.4^{\mathrm{a}}$ & $50^{\mathrm{a}}$ & $178^{\mathrm{a}}$ \\
\hline$C x$. tigripes & $15^{\mathrm{a}}$ & $10.1^{\mathrm{a}}$ & 33.7 & $11.43^{\mathrm{a}}$ & $0^{\mathrm{b}}$ & $0^{\mathrm{b}}$ & ND & ND & ND & ND & ND & ND & ND \\
\hline$P$ value & $0.156 \mathrm{~ns}$ & $0.522 \mathrm{~ns}$ & & $0.018^{*}$ & $0.008 * *$ & $0.008 * *$ & $0.268 \mathrm{~ns}$ & $0.099 \mathrm{~ns}$ & $0.196 \mathrm{~ns}$ & $0.238 \mathrm{~ns}$ & $0.082 \mathrm{~ns}$ & $0.008 * *$ & $0.181 \mathrm{~ns}$ \\
\hline
\end{tabular}

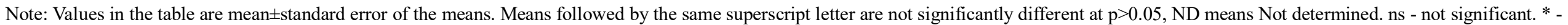

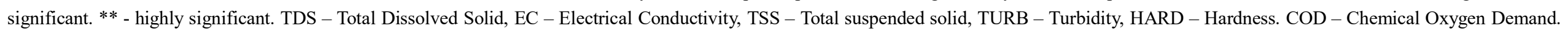
$\mathrm{PO}_{4}^{-3}$ - Phosphate, $\mathrm{NO}^{-3}$ - Nitrate, ALKA - Alkalinity 


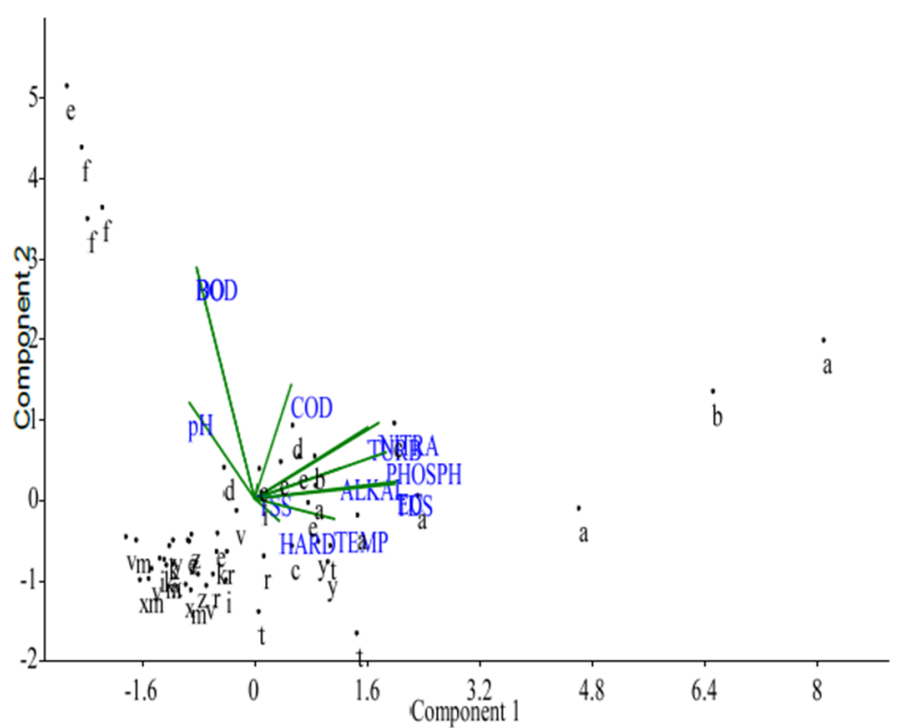

Figure 2 Interaction effect of the physicochemical parameters of the rock pools amongst the inselbergs

Note: a - Dumbi, b - Danmagaji, c - Hanwa, d - Dutsen-Abba, e - Kufena, f - Wusasa, g - Zango-Aya, i - Kujama, k - Tudu-Mare, $\mathrm{m}$ - Kagoma, r - Kajuru, $\mathrm{t}$ - Jere, $\mathrm{v}-$ Kwoi, $\mathrm{x}$-Nok, $\mathrm{y}$ - Chori, $\mathrm{z}$ - Samban-Gida

\section{Discussion}

This study unraveled the spatial distribution and ecology of preimaginal stages of culicine mosquitoes in the relatively accessible patchy rock pools on inselbergs as influenced by physicochemical factors. In this study, rock pools constituted discrete breeding microhabitats to Aedes and Culex mosquitoes responsible for transmission of several viral and filarial parasites that can cause severe disease and even death in humans. During the course of the study, these pools were maintained exclusively by rain which within three to four days becomes effective breeding habitats for mosquitoes. Since rock pools communities are completely dependent on length and frequency of inundations, the active community reflects the prevailing weather conditions (Jocque et al., 2010). Ranta (1982) observed that rock pool organisms can either have to escape from the habitat when conditions deteriorate or spend the unfavourable period in some kind of dormant forms. However, rain seizure during the preliminary stage of this work left some of the pools on the rocks with freshly filled rainwater without mosquito larva. This was evident on Danmagaji and Kufena inselbergs which recorded relatively low abundance of mosquito larvae amongst other inselbergs sampled for mosquito breeding in parts of Kaduna North. Similarly, rainless (break) period towards June ending may have accounted for the low volume or absence of waters in majority of rock pools and invariably the low population or absence of mosquito larvae particularly. This could be the cause of the negativity in the abundance of mosquito larvae on the Kufana inselberg in the central part of Kaduna State. The population of Ae. vittatus in the rock pools far outweighed the diversity of Culex species inhabiting the same microhabitats both in relative abundance and mean larval number per pool. The peculiarity of Ae. vittatus is its amenability for rock pools (Robinson, 1948; Hopkins, 1952). Hopkins (1952) identified true rock pool as the most preferred and characteristics breeding habitats of Ae. vittatus, and seldom breed elsewhere. This has been reported by Robinson (1948) who showed that stoney riverbeds and rock pools favour the breeding of $A e$. vittatus in Livingstone, Northern Rhodesia (Now Zambia). In contrast, Idowu et al. (2013) identified bamboo as breeding receptacle for Ae. vittatus in Abeokuta, Southwestern Nigeria. There was marked variation in the relative abundance of larval mosquitoes amongst the different vegetation zones of the State. Results revealed a high diversity in species compositions of Culex mosquitoes in the southern part of the State, yet with minimal larval abundance compared to the abundance of Ae. vittatus. This could be due to preference shown by Ae. vittatus for breeding in rock pool habitats over Culex mosquitoes. The study witnessed high relative abundance and mean number of mosquito larvae on Baban Sora, Kagarko, Malali and Wusasa inselbergs which exceeded by far the relative abundance of those of other inselbergs with relatively more number of rock pools. This observation conformed to the proposition by Adebote et al. (2008) that the more diversified the availability of rock pools on inselbergs, the less are the relative abundance and mean number of larval mosquitoes per pool. 
Results of this study showed that Ae. vittatus bred in shallow pools $(0.4 \sim 41 \mathrm{~cm}$ shallow than most pools where other species of mosquito larvae were found) and this probably underline the reason why they were more abundant in Sudan savannah compared to the central and southern Guinea Savannah. It could probably be due to seasonal instability in the Sudan savannah which may have restricted oviposition, successful breeding and possible emergence of adult mosquitoes in the few available pools while prolonged rainfall in the southern Guinea savannah could have largely washed away most of the larvae from their characteristics shallow pools. Eggs of Aedes, Ochlerotatus and Psorophora species of mosquitoes have been reported to withstand desiccation and remain dry for months or even years but still remain viable and hatch when soaked in water (Service, 1997). This could explain the reason for prolific breeding of Ae. vittatus compared to other species in the Sudan savanna especially in the face of seasonal instability with respect to rainfall. Despite the diversity of Culex mosquitoes, they contributed minimally to larval population. The overall reduced larval population of Culex species could therefore be due to gravid Culex mosquitoes being highly selective in their choice of oviposition site. Clement (1963) reported that the presence of organic matter in breeding sites, whether sterile or putrid, renders water highly attractive for oviposition to Culex mosquitoes, which prefer such water to freshwater; the degree of the preference reflecting the extent of contamination normally found in the natural larval habitats. Rain-filled rock pools are largely clean freshwater and are therefore not the preffered Culex habitats hence the least number of Culex mosquitoes encountered in the rock pools. It is plausible that the relatively few Culex encountered were associated with few pools on the rocks that were rich in organic matter. Culex mosquitoes also breed in cleaner water but in artificial containers (Macdonald, 1960).

Anthropological influences such as unavoidable presence of humans either for adventure, quarrying or drying of harvested farm produce on the inselbergs are common distinctive features of inselbergs sampled in this study. Churches of various denominations have acquired and erected transit-like structures on some of the inselbergs which they utilized as outstations and camping grounds for special prayers throughout the seasons. Dutsen-Abba inselberg, though in close proximity to human habitation, was observed with patas monkeys gallivanting on top of the inselberg. These are remarkable reservoir hosts that probably play critical role for maintaining sylvatic cycle of yellow fever in the study area. Considering the highly anthropophilic and zoophilic behaviour of Ae. vittatus as well as competent vector of arboviruses, it is plausible to aver that the humans population within the study locations are greatly exposed to high risk of contracting yellow fever and dengue virus and as such could play key role in epidemic of these diseases. Religious camping and worshippers that congregate from different State and locations in and around Kaduna State for camping on the inselbergs could be important drivers in disseminating human arboviral diseases. The presence of potential vector population densities and indirect human activities on the inselbergs could establish possible epidemic of disease infection due to these vectors. Adebote et al. (2006) reported high yellow fever epidemic risk posture around Zaria due to elevated Ae. aegypti larval indices in peridomestic containers. The common house mosquito, Cx. pipiens pipiens feeds principally on birds, but will feed on humans, particularly when inside a house. This vector bred in area where control activities targeted against it is relatively rare besides the poor housing standard of inhabitants surrounding the inselbergs. Thatched-roof housing with mud-constructed modeling wall largely characterized the housing quality around Danmagaji, Dumbi, Dutsen-Abba, Kufena and Wusasa inselbergs in Sudan savanna parts of the State. Cx. pipiens pipiens females may travel up to $1.2 \mathrm{~km}$ in a single night in search of a blood meal, but generally are found within $0.8 \mathrm{~km}$ of their breeding habitat. They are the most important primary vector (feed on birds and maintain West Nile Virus in bird population) as well as bridge vector of WNV. Culex albiventris, Cx. horridus, Cx. macfiei, Cx. perfidiosus and $C x$. simpsoni are zoophilic and bridge vectors (feed on numerous animal species including horses, humans and birds and move the virus from bird to mammal) of WNV. The presence of these bridge vectors in this region where the cultural heritage of the inhabitants are endowed with high affinity to domesticate horses used for their numerous festive activities could also portend an outbreak of West Nile Virus within the study locations. Culex tigripes is predaceous on other mosquito larvae and as such serves as natural biological agent (Gillies and De Meillon, 1968). 
Many species of mosquitoes are very specific in their requirement of physicochemical characteristic of their breeding waters. The prevailing physicochemical parameters of rock pools are important factors for survival and development of mosquito. This study observed an overall wide temperature range slightly above the optimum temperature $\left(31{ }^{\circ} \mathrm{C}\right)$ considered for rapid larval and pupal development (Oyewole et al., 2009). Below a developmental temperature threshold no growth occurs; above the threshold the rate of growth increases with increasing temperature, reaching a maximum at the so-called 'optimum temperature' above which it declines (Clement, 1963). This apparent temperature increase over the optimum within the rock pools could be attributed to height and exposure of the inselberg above the ground positioning the pools to direct incident radiation from the sun. In addition, the granitic nature of the inselbergs allows for rapid absorption and retention of heat from the sun. Jocque et al. (2010) observed that water temperature in rock pools depends on climate and seldom exceeds $40^{\circ} \mathrm{C}$ because of the balance between cooling through evaporation and heating by insolation. The temperature at which development proceeds fastest varies at different stages of development but the development of the larval and pupal stages has been considered as a whole to be most rapid at $31^{\circ} \mathrm{C}$ (Clement, 1963). The depth of the rock pool habitats has been shown to influence the species abundance of mosquito breeding therein. Results of this study showed that Ae. vittatus breed prolifically in shallow pools. This could be a natural selective pressure that controls the immigration of its potential predators into such shallow pools as they appeared to be somewhat constrained to deeper pools. Habitat size also influences the species composition of mosquitoes in rock pools. Rock pool habitats with large surface areas $\left(1.5 \sim 1970 \mathrm{~m}^{2}\right)$ were observed to be densely inhabited with tadpoles of both frogs and toads which are natural enemies of mosquito larvae. Habitats with large surface areas tend to have higher immigration and often offer a wider range of microhabitats/niches and decreased local extinction, which result in higher species diversity (Kumar and Hwang, 2006). Mosquitoes use chemosensory information to assess several parameters that reflect habitat quality for the offspring, including the availability of nutrients, the presence of competitors and predators, and the overall quality and permanence of the water body (Kumar and Hwang, 2006). Semiochemicals emitted from predators are normally used by mosquitoes to detect a predator's presence in the environment, and then mosquitoes can thereby minimize such encounters (Kats and Dill, 1998). Therefore, the active avoidance of habitats with a high predation risk by oviposition adult female mosquitoes may ultimately act to sustain high densities of mosquitos' larvae in the rock pools. Since rock pools are mosaically distributed habitats, the restriction of the congeneric or heterogeneric species of mosquitoes to varying distances of the rock pools is presumed to be due to discrimination by ovipositing females, an activity which will be affected in the long term by selective pressures operating during the larval stage as well as by those effective at oviposition. The fact that female mosquitoes are highly selective in nature in their choice of oviposition site has prompted the suggestion that the distribution of larvae is controlled not by survival in suitable and extinction in unsuitable habitats but by the discrimination of the ovipositing female (Clements, 1963).

This study underlines the fact that neutral to strong alkalinity $(2.0 \sim 111.0 \mathrm{mg} / \mathrm{L}$ for Ae. vittatus, $14 \sim 83 \mathrm{mg} / \mathrm{L}$ for An. gambiae, 33 50 mg/L for Cx. perfidiosus) were associated with the abundance of mosquito larvae, and thus play pivotal role for their prolific breeding in rock pool habitats. When $\mathrm{pH}$ was within the range of 5.5 to 8.5 , a balance in an ecosystem was maintained. Increased surface $\mathrm{pH}$ in water bodies could be due to increased metabolic activities of autotrophs, since they generally utilize the carbondioxide and liberate oxygen thus reducing $\mathrm{H}^{+}$ion concentration (Clement, 1963). Since Ae. vittatus accounted for more than $90 \%$ of mosquito larvae observed in this study, it can therefore be added that strong alkalinity may be a strong indicator for their choice of breeding in rock pool habitats. Rock pools sampled in this study were largely devoid of organic nutrients which tend to decrease the $\mathrm{pH}$ of the environment due to carbonate chemistry (Bellingham, 2013). In the laboratory, acid conditions are sometimes unfavourable to larvae but this may be due to the bacteria which develop under acid conditions or to the acid present, hydrochloric acid, for example, being more toxic than phosphoric acid (Clement, 1963). This view is somewhat generally accepted but unfortunately the means by which gravid female select the oviposition sites are very incompletely known (Clement, 1963). According to CDC (2004), water of a near neutral $\mathrm{pH}$ of 6.8-7.2 is preferable for breeding of many species of mosquitoes. Water $\mathrm{pH}$ higher than 7 but lower than 8.5 according to Abowei (2010) is ideal for biological productivity, but $\mathrm{pH}$ less than 4 is detrimental to aquatic life. Lower values of $\mathrm{pH}$ are indicative of high acidity, which can be caused by the deposition of acid forming 
substances in precipitation (Lawson, 2011). Electrical conductivity (EC) and Total dissolved solid (TDS) obtained in this study were largely below detectable limit with the HANNA instrument. This corroborates the report of Ranta (1982) that the small nature of the volume of water in rock pools results in strong fluctuation in electrical conductivity. Jocque et al. (2010) also observed that rock pools were characterized by low conductivity immediately after filling, typically fluctuating between 10 and $30 \mu \mathrm{S} \mathrm{cm}^{-1}$. As the water evaporates, conductivity increases mainly because of the concentration of metabolites and can reach values up to1400 $\mu \mathrm{S} \mathrm{cm}^{-1}$ in pools with the longest hydroperiod (Jocque et al., 2010). Huggett and Griffiths (1986) and Daniel and Boyden (1975) related the communities occurring in rock pools with the extremes of salinity, hydrogen ion concentration, light and temperature occurring within them. They identified temperature and oxygen concentration were the most important of these parameters that were particularly important in controlling community structure of the rock pools. It is pertinent to state like Jocque et al. (2010) that oxygen could also be introduced into water of the rock pools by green aquatic plants and algae during photosynthesis. This study revealed that inorganic nutrients such as nitrate, phosphorus, hardness, total suspended solid, alkalinity, chemical oxygen demand and turbidity had no significant effect on the abundance of mosquito larvae breeding in rock pools. This is in agreement with the observation of Jocque et al. (2010) that nutrients such as nitrate, phosphorus, alkalinity etc. declined quickly because of nutrient uptake by organisms and a reduced rate of nutrient supply from the sediment. Immediately after filling, dissolved nitrogen and phosphorus concentrations may be quite high but nutrients in the sediment get into the water via bioturbation by tadpoles and some crustaceans (e.g. Notostraca and Spinicaudata) (Jocque et al., 2010). Published data on nutrient availability on inselbergs indicated that phosphorus and nitrogen were severely limited (Dörrstock et al., 1996). Removal of nutrients from the system was largely by flushing by intense rain, sediment erosion by wind and, to a lesser extent, by terrestrial predators and scavengers removing organisms from the pool basins, and possibly also by the emergence of adult insects (Jocque et al., 2010). Nitrate and phosphate are major inorganic nutrients that are required by phytoplanktons. Algal growth is limited by phosphorus such that presence of additional phosphorus compounds can stimulate algal productivity and enhance eutrophication processes (Kenea et al., 2011). But another predator mosquito, Culex tigripes, was encountered at very low density on the Nok inselberg. Since prey vulnerability is a product of prey encounter rates with and ease of capture by the predator (Kumar, 2005; (Shaalan et al., 2007), certain behavioural attributes of mosquito species that determine capturability, and their relative proportions in the habitats could explain the observed mutually negative interaction amongst the predators and mosquito larvae in the rock pool habitats.

\section{Conclusion}

This study established and confirmed the breeding affinity of notorious vector of dengue and yellow fever vector (Ae. vittatus) in rock pools more than any other diverse breeding media available for this vector and those documented by other authors in Nigeria. This is a significant observation. Aedes vittatus was by far, the most dominant mosquito encountered in the twenty one sampling locations. Epidemiologically, encountered mosquito species were potential vectors of yellow fever, dengue, West Nile Virus and encephalitis. The anthropogenic activities observed on the inselbergs along with weather could be responsible for sustaining the risk of disease vectors and the spread of vector-borne diseases, thus extension of their geographic distribution in the study area. The abundance and distribution of preimaginal stage of mosquitoes in rock pools is supported by the physicochemical condition of the rock pool habitats. Therefore, rock pools should be inspected to incriminate vectors and need to be incorporated in mosquito control equations. Use of mosquito control tools that will not ruin or harm biological control prospect but which incorporate indigenous community participation should be contemplated in rock pools to stem vectorial roles of identified species.

\section{Authors' contributions}

OAO drafted the manuscript. DAA and IHN participated in the design of the study. OAO performed the statistical analysis. DAA and IHN conceived of the study, and participated in its design and coordination. All authors read and approved the final manuscript.

\section{Acknowledgments}

The authors are thankful to indigenous volunteers that assisted during sample collection within Kaduna State. We are also grateful to village heads that granted access to climb and sample their inselbergs in the study area. 


\section{References}

Abowei J.F.N., 2010, Salinity, dissolved oxygen, pH and surface water temperature conditions in Nkoro River, Niger Delta, Nigeria. Advanced Journal of Food Science and Technology, 2(1): 16-21

Adebote D.A., Oniye S.J., Ndams I.S., and Nache K.M., 2006, The breeding of mosquitoes (Diptera: Culicidae) in peridomestic containers and implication in yellow fever transmission in villages around Zaria, Northern Nigeria, Journal of Entomology, 3: 180-188 https://doi.org/10.3923/je.2006.180.188

Adebote D.A., Oniye S.J., and Muhammed Y.A., 2008, Studies on mosquitoes breeding in rock pools on inselbergs around Zaria, northern Nigeria, Journal of Vector Borne Diseases, 45: 21-28

American Public Health Association, 1998, Standard Methods for the Examination of water and wastewater,20 ${ }^{\text {th }}$ Edition, United Book Press, Inc.,Baltimore, Maryland, pp.12-67

Bellingham K., 2013, Physicochemical Parameters of Natural Waters, Retrieved from Stevens Water Monitoring Systems. Inc.(http 4)

Center for Disease Control and Prevention, 2004, Life stages of Anopheles mosquitoes, Mobidity and Mortality Weekly Report, 52: 989-997

Clements A.N., 1963, The physiology of mosquitoes: relationship of plankton to anopheline larvae, Pergamon press, pp.68-310

Daniel M.J., and Boyden C.R., 1975, Diurnal variations in physico-chemical conditions within intertidal rock pools, Field Studies, 4: 161-176

Day J.F., 2016, Mosquito oviposition behavior and vector control, Insects, 7(4): 65

https://doi.org/10.3390/insects7040065

PMid:27869724 PMCid:PMC5198213

Dejenie T., Yohannes M., and Assmelash T., 2002, Characterization of mosquito breeding sites in and in the vicinity of Tigray Microdams, Ethiopian Journal of Health Science, 21(1): 57-66

https://doi.org/10.4314/ejhs.v21i1.69045

PMid:22434986 PMCid:PMC3275853

Dörrstock S., Porembski S., and Barthlott W., 1996, Ephemeral flush vegetation on inselbergs in the Ivory Coast (West Africa), Candollea, 51:407-419

Famakinde D.O., 2018, Mosquitoes and the Lymphatic Filarial Parasites: Research trends and budding roadmaps to future disease eradication, Tropical Medicine and Infectious Disease, 3(4):1-10

https://doi.org/10.3390/tropicalmed3010004

PMid:30274403 PMCid:PMC6136629

Gillies M.T., and Demeillon B., 1968, The anophelinae of Africa south of the Sahara (Ethiopian Zoogeographical Region, South African Institute for Medical Research,54:343

Hopkins G.H.E., 1952, Mosquitoes of the Ethiopian region I- Larval bionomics of mosquitoes and taxonomy of culicine larvae,British Museum (Natural History), London,pp. 355

Huggett J., and Griffiths C.L., 1986, Some relationships between elevation, physico-chemical variables and biota of intertidal rock pools, Marine Ecology-Progress Series, 29:189-197 https://doi.org/10.3354/meps029189

Idowu O.A., Adeleke M.A., and Aina T.M., 2013, Evaluation of indoor breeding activities of mosquitos during the dry season in Abeokuta, Southwestern Nigeria, Journal of Environmental Health Research, 12(1):1-5

Jocque M., Vanschoenwinkel B., and Brendonck L., 2010, Freshwater rock pools: a review of habitat characteristics, faunal diversity and conservation value, Freshwater Biology, 55(8):1587-1602 https://doi.org/10.1111/j.1365-2427.2010.02402.x

Kats L.B., and DillL .M., 1998, The scent of death: Chemosensory assessment of predation risk by prey animals, Ecoscience,5(3):361-394 https://doi.org/10.1080/11956860.1998.11682468

Kenea O., Balkew M., and Gebre-Michael T., 2011, Environmental factors associated with larval habitats of anopheline mosquitoes (Diptera: Culicidae) in irrigation and major drainage areas in the middle course of the Rift Valley, central Ethiopia, Journal of Vector Borne Diseases, 48:85-92

Kumar R.,2005, Feeding modes and associated mechanisms in zooplankton, In:Kumar, A, (Ed), Ecology of plankton, Daya Publishing House, New Delhi, pp.228-265

Kumar R., and Hwang J.S., 2006, Larvicidal efficiency of aquatic predators: Aperspective for mosquito control, Zoological Studies, 45(4):447-466

Lawson E.O., 2011, Physicochemical parameters and heavy metal contents of water from the mangrove swamps of Lagos Lagoon, Lagos, Nigeria, Advances in Biological Research, 5(1):8-21

Levas S., 2006. Dynamics of supralittoral freshwater rock pools in the Gulf of Maine, Cornell University, Senior Honours' Thesis. pp23

Lindenmayer D.B., Michael D.R., and Cunningham R.B., 2008, A forgotten habitat? Granite inselbergs conserve reptile diversity in fragmented agricultural landscape, Journal of Applied Entomology, 45:1742-1752

https://doi.org/10.1111/j.1365-2664.2008.01567.x

Macdonalds W.W., 1960, On the systematics and ecology of Armigeres subgenus Leicesteria (Diptera: Culidae), Studies from Institute of Medical Reserves, 29:110-153

Nigeria Population Commission, 2006, Retrieved August 10,2013, at 10:30 am from (http: //www.kadunastate.gov.ng/user_contentphp)

Nigerian Arts and Culture Directory Project, 2013, Retrieved August 10, 2013 at 10:30 am from (http//:www.kadunastate.gov.ng/user_contentphp)

Obi O.A., Nock I.H., Adebote D.A., and Nwosu L.C., 2017, Ecological and molecular observations on Anopheles species (Diptera: Culicidae) breeding in rock pools on inselbergs within Kaduna State, Nigeria, Molecular Entomology, 8(1):1-10

https://doi.org/10.5376/me.2017.08.0001 
Journal of Mosquito Research 2019, Vol.9, No.5, 35-48

http://emtoscipublisher.com/index.php/jmr

Olayemi I.K., Omalu I.C.J., Famotele O.I., Shegna S.P. and Idris B., 2010, Distribution of mosquito larvae in relation to physico-chemical characteristics of breeding habitats in Minna, North Central Nigeria. Review in Infection, 1(1):49-53

Oyewole I.O., Momoh O.O., Anyasor G.N., Ogunowo A.A., Ibidapo C.A., Oduola O.A., Obansa J.B., and Awolola T.S., 2009, Physico-chemical characteristics of Anopheles breeding sites: Impact on fecundity and progeny development, African Journal of Environmental Science and Technology, 3(12):447-452

Rajesh K., Dhanasekaran D., and Tyagi B.K., 2013, Survey of container breeding mosquito larvae (Dengue vector) in Tiruchirappalli district, Tamil Nadu, India, Journal of Entomology and Zoological Studies, 1(6): 88-91 NEED TO BE DELETED.

Ranta E., 1982, Animal communities in rock pools, Annale Zoologici Fennici, 19:337-347

Robinson G.G., 1948, Mosquitoes caught in Northerm Rhodesia at Balovale and Livingstone, Journal of the Entomological Society of Southern Africa, 11:1-6

Rueda, L.M., 2008, Global diversity of mosquitoes (Insecta: Diptera: Culicidae) in freshwater, Hydrobiologia, 595:477-487 https://doi.org/10.1007/s10750-007-9037-x

Service M.W., 1976, Mosquito ecology field sampling methods, Applied Science Publishers Limited, London pp. 76-77

Service M.W., 1997, Medical Entomology for Students, Chapter1:Introduction to mosquitoes, (Culicidae), Third Edition, Cambridge University Press, pp.1-10 https://doi.org/10.1017/CBO9780511811012.005

Shaalan E.A., Canyon D.V., Reinhold M., Yones W.F.M., Abdel-Wahab H., and Mansour A., 2007, A mosquito predator survey in Townsville, Australia and an assessment of Diplonychus sp. and Anisops sp. predatorial capacity against Culex annulirostris mosquito immatures, Journal of Vector Ecology, 32(1):16-21 https://doi.org/10.3376/1081-1710(2007)32[16:AMPSIT]2.0.CO;2

Wallenstein F.M.,Peres S.D.,Xavier E.D., and Neto A.I., 2010, Phytobenthic communities of intertidal rock pools in the eastern islands of Azores and their relation to position on shore and pool morphology, Life and Marine Science, 27:9-20 